\title{
JELENTÉS A FRONTRÓL
}

\section{DOMONKOS KATALIN}

az Eötvös Loránd Tudományegyetem Neveléstudományi Intézetének doktorandusza

kati.domonkos@gmail.com

Célom egy roma tanulók nevelésével foglalkozó szegregált oktatási intézmény természetes közegben való megismerése, a szegregációnak, az együttélésnek, az együttmunkálkodás jellegzetességeinek vizsgálata az intézményben dolgozó pedagógusok és az ott tanuló hátrányos helyzetü tanulók nézöpontjából. Nem törekszem általánositásra, sokkal inkább annak az „egyedi sajátosságokkal biró” helyszínnek a bemutatására, ahol dolgozom, amely végül kutatásom tárgyává is vált.

\section{Önazonosítás}

Mielőtt hozzákezdenék az esettanulmány bemutatásához, fontosnak tartom röviden bemutatni önmagam, hozzáállásomat a problémakörhöz. Úgy gondolom, ezzel válik teljessé tanulmányom. Írásom értelmezéséhez, megértéséhez nélkülözhetetlennek tartom „gyónásom”, egyrészt azért, mert az általam átélt élményeket, helyzeteket mesélem el, akarva akaratlanul is szelektíven, továbbá az impressziók, dialógusok személyiségem szürői által kiváltott hangsúlyokkal válnak a vizsgálódás, rendszerezés ,áldozataivá”. Másrészt, elkerülhetetlennek tartom beavatni az olvasót a tekintetben, hogy ezeket a „szürőkőket”, milyen élmények alakították. Gondolatmenetemet egyértelmübbé teheti Elliot Aronsontól (2001/2003) kölcsönzött gondolat: „Annak, akik saját bőrükön sosem tapasztalták az elöítéletet, nem mindig könnyü teljes egészében felfogniuk, mit is jelent az, ha valaki egy előítélet célpontjává válik. Az uralkodó többség viszonylagos biztonságában élő tagjának többnyire nagyon nehéz beleérezni az elöítélet áldozatának szenvedésébe." (Aronson, 2003, 53. o.). Az, hogy az előbb idézett gondolat mit jelent számomra, jól megvilágíthatja egy saját naplómból vett idézet: „,Neveléstudomány szakos bölcsész lettem. Én, akinek általános iskolában azt mondták a tanárai, nem jó ötlet gimnáziumba jelentkeznem, mert úgysem tudom majd befejezni. Én, akinek gimnáziumban azt mondták a tanárai, hogy nem volt jó ötlet ide jönnöm, mert ez az iskolatípus azoknak való, akik föiskolára, egyetemre „valók” (?). És legyek reális, én nem oda való vagyok. Majd egy borzalmas érettségi és még annál is borzalmasabb hat év után (nőiruha-készitö szakmunkás-bizonyitvány és többek között varrónői munkatapasztalattal), úgy döntöttem, maradok irreális. Jelentkeztem a föiskolára (ELTE TÓK). Majd egyetemre 
(ELTE PPK). És most 36 évesen, itt állok már megint egy jeles érdemjeggyel zárult államvizsga után." [2011.07.02.]

A fenti „vallomástöredék” rávilágít arra, elsősorban mi motivált arra, hogy pedagógus legyek, de megmutatja azt is, miért akartam ebben az iskolában dolgozni, és mi okból választottam ennek a témának a vizsgálatát. De az önvizsgálat kutatásomnak csak elindítója, továbbmozdítója azonban az iskolai élet szereplöinek megismerni, megérteni vágyása. A napi történések, gondolatok rögzítésére naplót írtam, elsőként nem kutatási célzattal, csak szerettem volna tapasztalataimat, fejlődésemet megörökíteni, nyomon követni. Végül tanulmányom vázát e naplónak köszönhetem.

\section{Az iskola környezete}

A városrész, ahol az iskola épült egy település perifériáján helyezkedik el. A rendszerváltás előtt az iparban dolgozó tisztviselők éltek itt, a számukra épített házakban. A korábban vonzó lakóterület slumosodása a gyárak bezárása után indult el. A folyamat együtt járt a népesség kicserélődésével is. Az ipari létesítmények felszámolásakor sokan elköltöztek. Azok maradtak, akiknek nem volt hova menni, vagy ragaszkodtak eddigi környezetükhöz. A megüresedett lakások váltak szükséglakásokká. A rendszerváltás után a már régebben itt élő rokonok hívására újabb családok érkeztek, és lakóhely hiányában a megüresedett telepi lakásokba költöztek be olykor legálisan, néha önkényes lakásfoglalókként.

A telep a város szociális szempontból legelmaradottabb területe. Az épületek az 1900-as évek elején és közepén épültek. A lakások minősége, komfortfokozata megfelelt az akkori városi átlagnak. Mára az épületek állaga vegyes, a régi épületek maradtak fenn eredeti állapotukban, illetve épültek át. A 30-50 $\mathrm{m}^{2}$ közötti nagyságú lakásokban általában hat-nyolc ember lakik. A családok közül sokan a telephez tartozó garázssoron laknak. A lakások jelentős hányada komfort nélküli lakás. A komfort nélküli épületekbe az ivóvíz sincs bekötve, a vízellátást közkutakról biztosítják. Az épületek a karbantartás és a fütés hiánya miatt is nedvesek.

Az önkormányzat a telep felszámolására programot indított el, amelynek keretében az itt élő családoknak a város egy másik területén lakásokat biztosított. A programot az időközben megüresedő telepi házakba folyamatosan beköltözők miatt nem tudták folytatni. A népesség száma az elmúlt években a folyamatos beköltözések miatt nem csökkent.

\section{Az iskola bemutatása}

Az általános iskola épülete a telep szomszédságában található. Az iskola az 1900-as évek elején épült. Az udvarról nézve, a felújítások, korszerüsítések ellenére az épület állaga leromlott. Szembetünő a hátsó kerítés hiánya, kérdésemre megtudom, hogy „szép lassan elhordták”. Az udvaron lebetonozott focipálya, hátrébb fém mászóka. 
Az iskolába belépve a látogató a portával néz farkasszemet, karbantartott széles folyosók, lépcsők, magas, nagyméretü tantermek jellemzik. Az alsó tagozat tantermei színesek, barátságosak (gyerekek munkái, szemléltető eszközök a falon), interaktív táblával felszereltek. Valamennyi tanulónak önálló, egyszemélyes, nem rögzített asztala van, nem frontális elrendezésben. Ezzel szemben erős kontrasztot mutatnak a felső tagozatos termek, elsőként a sivár jelző jut eszembe. Nagyrészt üres falak, csak pár régi gyerekmunka, vagy irodalmi személyek portréi, a gyerekek kötött csoportokban helyezkednek el, a régi összekapcsolt kétszemélyes padsorok minden teremben, frontális elhelyezésben. Ezekben az iskolai tér egyáltalán nem, vagy csak nehezen alakítható, nehezen igazítható a különbözö tanulási helyzetekhez. Kivételt ez alól csak egy terem képez, amely barátságosabb a többinél, itt a falak jobban kitöltve a tanulók alkotásaival, szemléltető eszközökkel, valamennyi tanulónak önálló, egyszemélyes, nem rögzített asztala van, igaz frontális elrendezésben, de az asztalok elmozdíthatóak, ezért könnyen csoportokat lehet kialakítani. A vizuális és médiaismeret tantermen kívül a szaktantermi rendszer nincs kiépítve.

A régi iskolaépületekhez hasonlóan a folyosón és a lépcsőházon kívül nincs az iskolaépületben további köztér (például aula). Ennek hiányában az ünnepségeket jó idő esetén, az udvaron, rossz idő esetén a tornateremben vagy az ebédlőben tartják meg.

\section{A tanulókról}

A fent már említett változások (gyárbezárás, nagyfokú munkanélküliség) az iskola tanulói összetételében is jelentkeztek. A rendszerváltás idején a roma tanulók aránya öt-tíz százalék között volt, jelenleg több mint kilencven százalék. A nyolc tanulócsoportot foglalkoztató iskola a megváltozott körülményekhez nehezen tud alkalmazkodni. Az intézmény körzetében élő családok súlyos anyagi gondjai és nehéz életkörülményeik hatása több területen is megnyilvánul. A szükösebb anyagi eröforrások következtében jellemző a nem megfelelő, egyoldalú táplálkozás, hiányos ruházat, zsúfoltabb, egészségtelen lakáskörülmények, kevesebb ráfordítás az iskolai felszerelésre. A gyermekek ingerszegény körülmények között élnek. A családoknál gyakori az alkoholfogyasztás, a konfliktusok eröszakos megoldása, valamint a munkanélküliség.

Az iskolában magas az igazolatlan mulasztók aránya, rendszeres a rendbontás az órán, a rongálás, a fizikai bántalmazás a gyerekek között, a verbális agresszió, ordítozás, agresszív magatartás az iskola dolgozóival, dohányzás.

„Állandóan káromkodnak. Nyomdafestéket nem türö hangon, stílusban beszélnek. Mondják, kiabálják nekem, egymásnak, báty a húgának, húg a bátyjának, órán, szünetben. Elsős, másodikos... mindenki, mindenhol. Még meghallom. Még szólok, hogy nem kéne. Cseréld le a kótyomfittyre, ebugattára. Persze nem veszik komolyan, persze én sem. Most már tudom, súlyát vesztett szavak ezek. Olyan, mint ne- 
kem a jó reggelt. Csak nem akarom a hallgatással támogatni. Csak jó lenne, ha legalább 1-2 percig nem hallanám valakitöl, valamerröl."

„A terembe bejönnek. De körülbelül ennyi a többség részéröl. Ha már annyit szólok hozzá, hogy legyen olyan kedves, vegye elö a füzetét, általában kezdödik: „Nem veszem elö. És akkor mi van. Úgy sem tud mit csinálni. Nincs joga belenyúlni a táskámba. Nincs joga igazolatlan órát adni, mert bent vagyok a terembe. Nincs joga semmihez." Röhögés. És tényleg. Itt állok a teremben egyedül, velem szemben 22 dühös diákkal, akik utálják az iskolát és engem. Azt azért nem, inkább csak tanulni utálnak (már) és a pedagógust utálják. És én mindeközben azon gondolkodom, hogyan tudnám kiegyenlíteni, semlegesiteni, megoldani itt és most, egyedül ebben a teremben mindazt a gyülöletet, elutasitást, agressziót, ami feléjük áramlik a világból. Feléjük, cigányok felé, a magyaroktól, cigányoktól, családjuktól, testvéreiktöl, apjuktól, anyuktól."

A városrész lakóinak végzettség szerinti megoszlása rendkívül kedvezötlen (8. évfolyamnál alacsonyabb iskolai végzettség: $35,5 \%$, felsőfokú végzettséggel rendelkezők: 2,35\%, KSH, 2008). A városrész helyzete gazdasági aktivitás szempontjából sem mondható kedvezőnek, hiszen a foglalkoztatási arány: 27,2\%, a munkanélküliségi ráta: $31 \%,(K S H, 2008)$. A szülök többsége iskolázatlan, a tanulásban keveset, vagy egyáltalán nem tudnak segíteni gyermeküknek. Nem tartják a kapcsolatot az iskolával, a pedagógusokkal. Ennek mértékére azonban csak elméletben voltam felkészülve. A valóság megdöbbentő és kijózanító volt számomra.

„Bejött egy apuka, hogy be akarja íratni a kislányát az iskolába. Megkérdezték, hogy hivják a kislányt. Mondta: Melinda. Erre az igazgató megkérdezte: Milyen Melinda? Mi a vezetékneve? Ezután apuka: Azt nem tudom. Mi otthon csak Melindának hivjuk.” [2011. 10.04.]

„,Ma megtudtam, az egyik diákom anyukájáról, hogy analfabéta. Én meg kb. egy hete arra kértem, ellenörizze minden este, mit pakol be a lánya, mert mindig a másik heti holmiját hozza." [2011. 10. 29.]

„Ha az iskola felhivja a családot vagy beszél a szülövel, akkor csak a szidás, a problémák hajtogatása. Család nélkül senkik vagyunk. Miért csak akkor hívjuk be öket, ha baj van?" [2011. 09. 16.]

Mindezek miatt az intézményre különösen nagy feladat hárul a nevelés terén. Az iskola tanulói összetételének, a szegregációnak, a szegénységnek és a homogén szociális struktúrának a következménye, hogy magas a tanulási és magatartási problémákkal küszködő gyerekek aránya, a tanulók egymásra is rossz hatással vannak. „A szegénység, a gyermekkori magatartási zavarok közötti összefüggés, a kutatások adatai szerint, már 7 és 11 éves kor között is megjelenik, mégpedig oly módon, hogy az öt évnél hosszabb időt szegénységben eltöltött családok gyerekei között gyakrabban fordulnak elő a depresszió, az impulzivitás és az antiszociális viselkedés tünetei, mint a többieknél. A serdülőkorban és a serdülést követő években, szintén kimutatható a szegénység összefüggése a depresszióval, mint internali- 
zált tünetegyüttessel, valamint a drogfogyasztással és a bűnözéssel mint externalizált viselkedésformával." (Ranschburg, 2008, 107. o.) Ennek következtében a „tanárok egyre leterheltebbek, a gyerekek egymásra is rossz hatással vannak” (Szilvási, 2008, 25. o.), mindez együtt jár a pedagógiai munka minőségének romlásával. Iskolánkban a pedagógusoknak a napi oktatással egy időben, az alapvető szocializációs feladatokat is pótolniuk kell a kortársaikhoz képest, viselkedésfejlödésükben több évvel lemaradt diákjaiknál.

Az általam bemutatott iskola felső tagozatában további problémát okoznak a kedvezőtlen személyi és tárgyi feltételek. A pedagógusok körében magas a fluktuáció, továbbá több tantárgyat továbbra sem szakpedagógus oktat. Sok a más tagintézményböl áttanító pedagógus, akik hetente csak egy-egy nap vesznek részt az iskola életében. Mivel szaktanárok nagyon ritkán jelentkeznek, ezért minden továbbtanulási igényt támogat(na) az iskola, de ennek gyakorlati megvalósítása további nehézségek, konfliktusok forrása. A továbbtanulóknak plusz szabadság jár, konzultációra mennek, s helyettesíteni kell őket. Mindezek a törzspedagógusokra (felső tagozatban mindössze öt) további terhet rónak (helyettesítés, túlóra, ügyelet). A pedagógusok közérzetét tovább rontja, hogy mind társadalmi, mind rendszer szinten is munkájuk lebecsülését érzik, ezenfelül a pedagógustársadalom részéről is - racionális érvekre nem támaszkodó - értékítéletekkel kell szembesülniük:

„Ma azt monda az egyik, nem nálunk tanitó kolléga, hogy milyen jó nekünk veszélyességi pótlékot is kapunk, felelösség meg semmi. (...) Veszélyességi pótlék: bruttó 2400 Ft. Mondtam neki, cseréljünk. Nem akart!”.

\section{Kezdetek}

„Szeptember elsején elkezdödött a tanév. Gyed után, napközis nevelöként indultam (elötte is napközisként dolgoztam itt). Nem tartott sokáig. Két új felsős kolléga, másfél hét után feladta. Lehetetlennek, értelmetlennek tartotta az itteni munkát. A kétszeres kolléga-hátraarc után az én életem is megváltozott.". [2011. 09. 09.] Hogy mennyire azt akkor még nem sejtettem. Elsőként hatalmas felelősséget éreztem, ezért hozzáláttam újdonsült tantárgyaim tanulmányozásához. Az első napon szembesülnöm kellett azzal, hogy felső tagozatban a legnagyobb problémámat nem tanítónői végzettségem okozza majd. Amint a gyerekek tudomására jutott, hogy én leszek a tanáruk, az addig barátságos felsősök ellenséges, támadó, provokatív és indulatos viselkedés vettek fel velem szemben (tekintélyszemély lettem?). A munkám során felmerülő nehézségekkel természetesen tisztában voltam, azonban a később tapasztalható mértékükre nem számítottam.

A munkám során tapasztalt leggyakoribb problémák: a tanulók érzéseiket azonnal, heves és intenzív formában juttatják kifejezésre; gyenge feladattudat, önkontroll; az alapismeretek hiánya; a követelmények elkerülése támadással. Viselkedésük kiszámíthatatlan; folytonosan konfrontációt kezdeményeznek, szándéko- 
san dühítenek másokat, ami sokszor a játékot „helyettesíti”. A legmegterhelőbb az egymást érő verbális és fizikai agresszió volt.

„A héten egy ötödikes lány leirt nekem egy „, b” betüt és megkérdezte, hogy ez mi. Egy hatodikos lány megkérdezte, milyen nap jön a hétfö után, a kedd vagy a szerda?"

„Egyik nap egy alsós kolléganövel ügyeltem az udvaron. Ügyeletes párjaink nem jöttek ki. Az iskola gyerekei 8-12 fös csoportokban verekednek. Rúgták, ütötték egymást, ahol érték. Elindultam szétszedni öket. Az elsö csoportot sikerült, indultam a következőhöz. Mire odaértem, az első csoport ott folytatta, ahol abbahagyta. Én szétszedtem öket, ök folytatták. Egy ideig így ment. Aztán megálltam, kérdön néztem a kollégámra, hátha a több mint tíz év tapasztalata tanácsot ad nekem. Csak nézett rám. Azt mondta, fogalma sincs, mit tegyünk. Körbenéztem. Egykét gyerek kivételével az egész iskola verekedett. Csak álltam. Ketten nem fogjuk tudni leállitani öket. Szerencsére becsöngettek, kijött a többi kolléga. Szerencsére senkinek sem lett baja."

Kezelésüket nehezítette, hogy ezek a problémák osztályonként csak egy-egy gyereket nem érintettek, a kollégáktól azonban csak általános tanácsokat kaptam. Mindezeken felül nem voltam benne biztos, hogy valójában segítség az, amit annak szántak, vagy biztos voltam benne, hogy nem segítség az, amit kapok, valamint túlzott elvárást is éreztem.

„Ha az elsö évet kibirod, utána már könnyebb lesz!”

„Az elsö két évem nekem is ilyen volt. Amig nem szeretnek meg ezek a gyerekek, addig esélyed sincs."

„,Ma megkérdeztem az egyik felsős tanárt, hogy fog-e ez nekem menni? Mert most nem úgy érzem. Nevetett, azt mondta, türelem, a gyerekek nehezen fogadnak el. És ha elfogadnak, akkor sem lesz sokkal könnyebb." [2011. 09. 28.]

„Egyik kolléga bejön az órámra, mert nagy a zaj. Természetesen „segíteni” akar. Odaszól az egyik fiúnak, aki ül és ir. Igaz papirra, mert nincs itt a füzete. „Ha az én órámon van füzeted, Kati nénién is legyen. Jóóó?” Tudom, hogy mindig gondja van a fiúval a saját óráján. Allandóan feláll, járkál, verekszik. (Másnap ugyanez a kolléga ugyanezt a gyereket kirakja az órájáról.)"

„Tanulószobás voltam, a gyerekek pedig vadak és öntörvényüek. Az 5. óra után már nincs tanári ügyelet sem, ezért egyedül vagyok az udvaron velük. Ráadásul a napközis kolléga kiengedte délután a gyerekeit, ö meg beült az irodába számitógépezni. Szerdán háromszor majdnem meglincselték, megkövezték egymást a gyerekek. Én álltam két felböszült banda között. Egyszer még bozóttüz is volt. A gyerekek bent a bozótban, én egyedül, a saját és mások csoportjával." [2011. 10. 20.]

„A helyettesitö tanárok az utolsó órát nem helyettesitették, kiküldték egyedül a gyerekeket az udvarra, aztán bementek. Én voltam kint 60 gyerekkel egyedül. Azért csak ennyivel, mert a többség hazament. Persze verekedtek. Sokan. Az igazgató kiszólt (nekem), hogy tegyek rendet." [2011. 11. 08.] 
„Első óra után azt mondta az igazgató: Kati, meg kéne fogni öket. Erre én: igen, szerinted mivel próbálkoztam odabent?" [2011. 09. 16.]

\section{Hogy éljem túl?}

Az új közösségbe kerülve, egyik első gondolatom az volt, hogy ez így szegregáltan lehetetlen. „Amit most csinálok, abban nem hiszek. Nem hiszem, hogy így szegregáltan van értelme őket oktatni, nevelni. (...) De azt is tudom, hogy a város magát „normálisnak” gondoló rétege nem fogadná el, ha egy első osztályos barna bőrü kislány azt mondaná egy fehér bőrü kislányának, hogy a rák egye meg a gyomrod. Mert ő ezt mondja, nem is ritkán. Ezt mondja, mert a telepen így oldják meg a dolgokat. És a pedagógus sem vállalná az első két (esetleg több) hónap fáradságos munkáját, hogy megszelídítse az osztályába került gyereket. Mert itt szelídíteni kell, nemcsak oktatni, nevelni."

„A szegregációval az a baj, hogy visszanyomjuk, söt lejjebb nyomjuk öket annál, ahol most vannak. (...) Ha pedig szegregálunk, nem hagyhatjuk, hogy pedagógus kollégáink egyedül oldják meg egy társadalom problémáját. Egy rosszul müködö társadalom következményét." [2011. 09. 16.]

Egy szegregált intézményben az első súlyos nehézséget az agresszió mértéke jelenti, valamint az, hogy nehéz differenciálni a különböző megnyilvánulásokat. Elsőként mindent (jobb híján) explorációs (felderítő) agresszióként azonosítottam, na meg azért is, mert ez esetben, ha a próbálkozás válasz nélkül marad, akkor az explorációs aktivitás növekszik (Csányi, 2000, 174. o.), amit természetesen próbáltam megelőzni. Ilyenkor a gyerekek próbálgatják, meddig mehetnek el. Én többnyire a tünetre reagáltam és büntettem, vagy valamilyen szankciót helyeztem kilátásba. Legalábbis próbáltam, hiszen egy új szereplőnek azt is ki kell tapasztalnia, hogy melyik diákra milyen módszer, milyen hatással van. Legtöbbször nem a büntetés segített közelebb a megoldáshoz.

„Az első nap 18-23 gyerek üvöltött velem szembe. Amúgy is nehéz a suli, de másfél hét alatt két tanárt készitettek ki, ezért vérszemet kaptak. Kötekedtek, káromkodtak, megdobáltak, megrúgtak..." [2011. 09. 16.]

„Az egyik fiút már tudom kezelni. Múltkor nagy nehezen sikerült elérnem, hogy menjen be arcot mosni. Jobban lett. Ma is mondtam neki (mikor láttam, hogy kezd indulatossá válni), hogy emlékszel, jobban lettél töle. Menj ki most is, és mosd meg az arcod." [2011. 09. 19.].

„Már-már úgy éreztem, elfogadtak. Nyugodtabb óráink voltak (a kezdetekhez képest), amikor az egyik tanuló dührohama közben az osztályból páran azt tanácsolták: ,,verjem meg, akkor majd abbahagyja”. Mondtam, hogy nem verek gyereket, az nem megoldás. Nem hitték el... Aztán kezdödött minden elölröl. Úgy érzem, eddig azt próbálgatták, meddig mehetnek el, most meg azt, hogy igazat mondtam-e, és tényleg nem bántom öket." [2011. 10. 06.]. 
„, Ma az egyik fiú megvárt az utcában. Azt mondta ö lesz a gyilkosom és a torkom felé irányitott egy faágat.” [2011. 09. 19.] (...) „,Akkor nem tettem semmit, csak elköszöntem töle. (...) Másnap elkértem az osztályfönökének egyik órájáról pár percre, hogy beszélgessünk az elözö nap történtekröl. Azon a héten sokat figyeltem öt órán, beszélgettem vele szünetekben is. Beszéltem az unokatestvérével, tanácsot, segitséget kérve töle. Megtudtam, hogy a fiú anyukája meghalt, a nagynénje neveli. Akkor már úgy éreztem, hogy nem büntetnem kell impulzivitásáért, hanem megerösiteni, ha az iskola szabályainak megfelelöen viselkedik. Két hét múlva elkísért a buszmegállóig, és már nem akar megölni, sőt még egy kicsit velem akart lenni, mielött hazamegyek! Nagyon kedves töle!” [2011. 10. 29.].

Majd ahogy beszélgettem a gyerekekkel, megismertem öket, és ök is engem. Egyenként, nagyon lassan és engem nagyon megdolgoztatva kezdtek elfogadni, elkezdtek kirajzolódni előttem magatartásuk mögött álló motívumok. Ebben az iskolában azonban az elfogadás nagyon lassú folyamat, és csak a fegyelmezési problémák enyhülésével jár együtt. Megfigyeltem, hogy a fegyelmezetlenség leggyakoribb oka nem a már említett explorációs agresszió, hanem a versengés a figyelemért és a valamiféle „beavatás”, aminek tétje a bizalom megszerzése. És a büntetéssel tulajdonképpen én fokoztam az agresszió mértékét.

„Nagyon szeretetéhesek. Sokszor ez szüli a konfliktust. Nem birják elviselni, ha mással is foglalkozom, és nem csak velük. Akit nem szeretnek, mindenáron azt akarja. Akivel nem törödnek, mindenáron kieröszakolja. Ha üvöltesz velem, még az is jobb, mintha átnéznél rajtam!" [2011. 10. 03.].

„Kati néni, ha majd kibir nálunk egy évet, akkor majd szót fogadok magának!”

Természetesen nem állítom, hogy a beszélgetések hatására a diákok már nem voltak fegyelmezetlenek, vagy hogy mindig sikerrel jártam, amikor a büntetés helyett valamilyen alternatív megoldást kerestem. Azonban lényegesen csökkent az órai rendzavarás mértéke azoknál, akikkel sikerült órák után beszélgetnem, vagy be tudtam vonni valamilyen tanítás utáni tevékenységbe, nagyra értékelték azt is, ha felfedeztem „erős oldalukat”. De a legjelentősebb változást akkor értem el, ha családot látogattam, $\mathrm{s}$ ha sikerült a szülővel elfogadtatnom magam.

„Az iskolaújság (és a szakkör) is azért jó (többek között), mert összeülünk, és nemcsak cikket irunk, hanem a vége mindig beszélgetés. És már most is olyan dolgokat osztanak meg velem az életükböl, amiröl én sosem beszélnék! Egy órás foglalkozásból fél óra beszélgetés, ami abból áll, hogy ök mondják, én hallgatok! (Sokkal többet tudok meg róluk, gondolataikról, érzelmeikröl, nehézségekröl így, mint órán.)" [2011. 10. 09.].

„Dávid még mindig utál (legalábbis ezt mondta), de ma megláttam a rajzait. Gyönyörüen rajzol. Mondtam neki. Megvárt a tanárinál, hozott még rajzot, hogy megmutassa. Ezek jó pillanatok." [2011. 10. 29.]

Az iskolámban a tanulók csalódását és dühét tovább fokozta az is, hogy míg alsó tagozatban, interaktív táblával, saját egyszemélyes asztallal felszerelt, munká- 
ikkal díszített termeik voltak, felső tagozatból mindez hiányzott. Márpedig a tanításhoz szükséges eszközök és feltételek jó minősége csökkenti a rendbontás előfordulását (Kósáné, 2005). Gyakoriak voltak az olyan megnyilvánulások, hogy „azok a ... elsösök elvették tölünk a termünket.”, vagy „,nincs itt semmi csak a falak, bezzeg az alsósok...”, vagy ,, bezzeg míg mi is alsósok voltunk”. Az iskola szintjén (is) megtapasztalt relatív depriváció, relatív megfosztottság (Aronson, 2003, 277. o.) növeli a frusztrációt, mivel saját csoportjuk helyzetét más csoportokhoz képest előnytelennek érzik, mindez szintén agresszióhoz vezet. Továbbá ezt olyan életkorban tapasztalják meg, amikor a család felől is nő az otthoni munkába való bevonás igénye.

„,Azok a ... elsösök elvették tölünk a termünket.”, ,,nincs itt semmi csak a falak, bezzeg az alsósok..."

„,Mire szül még egy gyereket, mikor már így is mindig rámsózza a kicsiket."

„Már maga is kezdi, otthon is mindig csak a takaritás, meg a rendrakás.",

„,Mindig csak a kicsik, meg vigyázz a kicsire. Így meg úgy a kicsik.”.

Fontosnak tartom megjegyezni, hogy mindez nem azt jelenti, hogy nem szeretik testvéreiket. Diákjaink életében nagyon fontos szerepet tölt be, mind a szüken, mind a tágan értelmezett család. A háttérben inkább az lehet, hogy nem a kistestvér felé forduló figyelmet tekinthetjük soknak, hanem a feléjük irányulót kevésnek.

A kényelmetlen és mozgásszegény iskolai környezet, vagy egy új munkaforma, módszer bevezetése is fokozta a fegyelmezetlenséget. A 45 perces tanórák és az osztálytermi frontális tanítás gyakorlatától eltérően, a páros, illetve a csoportmunka több mozgással járnak. A hagyományos értelemben vett fegyelem ebben az esetben nem értelmezhető. A beszélgetés, a mozgás a tanulás természetes velejárója lesz, már ha sikerül elérnünk. Ennek megvalósítása azonban nem egyszerü. Eleinte a diákok az előző napi történések megbeszélésére használják a feladatra kijelölt időt, de többen felháborodtak akkor is, mikor kipróbáltam az öndifferenciálás módszerét.

„Van olyan osztály, ahol eleinte annyira konfliktusos volt a gyerekek egymás közötti kapcsolata, hogy még a páros munka sem megy, nemhogy a csoportos." [2011. 10. 09.].

„Milyen tanár maga! Maga nem is tanár! Mi az, hogy én döntsem el (melyik feladatot oldja meg)! Mondja meg, mettöl meddig másoljuk le!" [2011. 10. 09.].

Egyúttal számolni kell néhány kolléga esetleges rosszallásával is, hiszen ők, mint külső szemlélők, csak a „hangzavart”, a „szigorúbb fegyelmezési technikák” hiányát tapasztalják, mindez többfrontos hadszíntérré változtatja a pedagógus mindennapjait. Gyakran okozta az osztályok felbolydulását az is, hogy a diákok az eröfeszítés és a siker, valamint az erőfeszítés hiánya és a kudarc közötti összefüggést nem észlelték. Ez leggyakrabban az értékelésnél okozott zavart. Úgy gondolták és ennek hangot is adtak, nem is akármilyen hangerővel, hogy aki jobb jegyet kapott, vagy akit megdicsértem azt ,jobban szeretem", illetve, akinek rosszabb jegyet adtam, vagy elmarasztaltam viselkedése miatt, azt „nem szeretem”. Ezt a problémát 
úgy láttam kezelhetőnek, hogy az osztályzat mellé pár szóval kiemeltem a munka erősségét, ami bizonyos esetekben eredményre vezetett.

A családi bevételek kiszámíthatatlansága is (számomra) nem várt nehézség forrásává vált. A hónap végi nélkülözés, a szükségletek kielégítetlensége miatt, a családi pótlék elött pár nappal már jelentkezik, az itt dolgozók által már jól ismert és máshoz nem hasonlítható nyugtalanság, feszültség az osztályokban. A diákok minden percét kitölti a várakozás felett érzett izgalom. Minden nap felkerül a táblára, hogy hány napot kell még várni a nagy napig. Rendszeres az órai bekiabálás.

„Tegnap megjött a családi pótlék. Most minden gyerek be van zsongva. (Van, aki reggelire energiaitalt iszik. Emiatt ma az egyik fiú kezelhetetlen volt). A táppénz érkezési idejéhez kéne igazitani a tanmenetet és az órarendet." [2011. 10. 06.].

„,Ma este már tali a Tescoba!” - miután a családtól megkapták az sms-t, hogy megvan a pénz.

„,Kati néni, apu azt mondta, ha megkapjuk a családit, megkapom az új cipöt! közben mutat a lyukas cipöjére." [2011. 10. 04.].

Erre a sajátos helyzetre megoldást jelenthetne a tanulmányi munka hagyományostól eltéró megszervezése, amikor a diákok tanrendje nem naponta és óránként változik, hanem a tananyag tömbösítve kerül feldolgozásra. Ez nemcsak azt tehetné lehetővé, hogy a gyermek figyelme tartósan egy-egy területre koncentrálódjon, hanem azt is, hogy az előre kiszámítható impulzívabb, nyugtalanabb időszakokra, mint például a családi pótlék érkezésének a hete, érdemes lenne inkább a vizuális kultúra, médiaismeret, tánc és dráma vagy ének-zene epochákban gondolkodni.

Pedagógusként gyakran találjuk szembe magunkat a deviáns mikrokörnyezet tanulóinkra gyakorolt hatásával is. Az agresszió látványa és tapasztalata a tanuló közvetlen környezetében is jelen van, a szülök számtalanszor így oldják meg problémáikat, konfliktusaikat. További problémaforrást jelent az agresszió iskolai aktív és passzív megerősítése is. Mindezek következménye, hogy később a gyermek is a felnőttektől elsajátított módon viszi véghez akaratát agresszív viselkedésével, ekkor tulajdonképpen egy olyan rögzült viselkedésformát próbál már a szülő, vagy a pedagógus megváltoztatni, ami a gyereknek, saját nézőpontjából jó, hiszen eddig célt ért vele, sikerélményt biztosított a számára. Előfordul azonban, hogy a szülő és a pedagógus sem támogatja az engedetlenséget, vagy agresszív megnyilvánulásokat, veszekednek miatta a gyerekkel, büntetik őt, de nem várnak el tőlük tényleges viselkedésváltozást (Katona és Szitó, 2005).

„Két tanárt már kicsináltunk, magát is kifogjuk.” [2011. 09. 20.]

„És akkor mi van, ha beszél vele, úgysem csinál majd semmit!"

„XY néni csak mondja, hogy megbüntet, aztán úgy sem lesz belöle semmi!”

„A ö nyelvük az agresszió, ezt tanulták, ezt értik."

„Csak akkor fognak elfogadni, ha te leszel a falkavezér. Vidd be valamelyiket a WC-be (mert akkor nincs szemtanú) rázd meg, ijeszd meg, mert csak ebböl értenek, és akkor, nyugalom lesz.". [2011.09. 16.] 
Az a pedagógus, aki ezt alkalmazza, figyelmen kívül hagyja, hogy az ember szocializációs lény, és a gyermek nem tesz mást, mint amire az általa megfigyelt, a környezetétől megtanult brutális dominancia (Csányi, 2000, 182. o.) szocializálja. Elfelejti azt, hogy különösen az ember esetében „tanulással az adott kultúra befolyása alatt az emberi agresszió egészen alacsony szintre szorítható és nagyon magas szintre is emelhetö." (Csányi, 2000, 173. o.). Továbbá megfeledkezik arról is, hogy az ember az állatoktól eltérően képes a szabálykövetésre (Csányi, 2000, 182. o.). Csakhogy ha egy családban nem követnek szabályokat, ha csak brutális dominanciával (eröfölénnyel) kényszerítik ki a felnőtt által elvárt viselkedést, akkor a gyermekből nem lesz szabálykövető felnőtt. „Szerencsénkre” azonban a szabálykövetés egy lazább közösségben (például iskola, társadalom) is megtanulható, épp ezért fontos hogy az iskolában ne az ököljog jelenjen meg (Csányi, 2000), hanem alternatív viselkedésminták meglétével, jutalmazásával, azonkívül átlátható, következetesen betartott szabályokkal, illetve áthágásuk esetére pontosan meghatározott azonnali, a cselekedet mértékével arányos szankciókkal neveljünk. „Az agresszió iskolai passzív megerősítése gyakrabban előforduló jelenség. Ennek igazolására Siegel és Kohn végzett kísérletének leírását érdemes felidézni, amelyben az agresszíven viselkedő gyermekek jelenlétében egy felnőtt nem tett semmit. Ezt a szituációt hasonlították össze azzal, amikor az agresszíven viselkedő gyermekek mellett nem volt felnőtt (lásd Ranschburg, 1995). Az eredmények alapján megállapítható, hogy szignifikánsan nagyobb mértékben viselkedett agresszíven az a gyermek, amelyik mellett a felnőtt elöször jelen volt, mint az, amelyik mellett nem. A hallgatás beleegyezésként, a viselkedés megerősítéseként értelmezhetö. Mindebböl az következik, hogy a nem kívánatos viselkedést nem szabad szó nélkül hagynunk, mert azzal megerősítjük.” (Ranschburg, 1995. 111. o.). Kivétel ez alól, mint már említettem, ha figyelemfelkeltés a normaszegő viselkedés célja.

Felfigyeltem arra a jelenségre is, hogy az iskolai prevenciós aktivitás mintha magasabb lett volna abban az esetben, ha enyhébb kihágásról, valamint az iskolával együttmüködőbb szülők gyerekeiről volt szó. Míg sokszor figyelmen kívül hagytuk, vagy csak tehetetlenül néztük a gyerekek közötti mindennapos, mindenórás verbális és fizikai erőszakot, addig rendszeresen lemosattuk a lányok körméről a körömlakkot (ami egyébként a lányok körében tovább növelte az aznapi engedetlenség mértékét). Továbbá, ha a szülök együttmüködők voltak az iskolával, akkor magasabb aktivitást mutattunk a diákok magatartási problémájának megváltoztatásával kapcsolatban, még akkor is, ha ez csekély mértékü volt.

Komoly nehézség az is, hogy a gyerekek nem tanultak meg játszani, vagy unatkoznak, ezért kötekednek, verekednek egymással, valamint egész egyszerüen nincs mivel játszani. Kezelése azért nehéz, mert az egyetlen megoldás az, ha rendszeresen használunk szemléltetőeszközöket, játékokat és megtanítjuk használatukat. Ezzel azonban a pedagógus egy időre az önként vállalt kudarc folyamatos és nem is akármennyire intenzív megélésére kényszeríti magát, törekvése csak akkor vezet eredményre, ha a rendszer és a környezet együttérzésével, megértésével párosul. 
„,Van egy felsös szakköröm, „ön- és társismeret", ami azt jelenti, hogy bevittem itthonról az összes társasjátékomat és azzal játszottunk. Az első alkalmat végig verekedték (Már az is vitát, verekedést váltott ki, hogy ki vegye elö a játékot.). Másodszor már csak veszekedtek!” [2011. 10. 03.]

„Náluk a játék a verekedés. Én meg utálom, le akarom állitani. De ahhoz játék kell. Legalább egy labda. De nincs. Semmi nincs. Csak én és két tucat gyerek. A foci az egyetlen, amit a fiúk játszanak (...) A leeresztett gumilabdával is játszottak." [2011.09. 28.]

„A gyerekeknek nincs semmije. Bevittem természetismeretre egy höméröt. Már nem verekedtek érte, mint a paprika-, és paradicsompalántáért. (Akkor összeverekedtek, mindenki egyszerre akarta megnézni. Mire szétszedtem őket, az egyik diákom megette a terméskezdeményeket. Erre megint összeverekedtek.). Kiabáltak, de kivárták, mire megnézhetik. Aztán felragasztottuk kivülröl az ablakra, és nézték, hogy megy le a mutató! [2011. 10. 20.]

Sokat emlegetett kérdés az is, hogy a rendszer a lehetőségek és erősségek helyett a hiányosságokat, problémákat hangsúlyozza. Paolo Freire szerint a „gyerekek agresszív viselkedése reakció a tananyag és az iskola világának azon körülményeire, melyek figyelmen kívül hagyják a gyerek történetét, kultúráját és mindennapi tapasztalatait" (idézi: Szilvási, 2008, 27. o.). A problémának ezt a dimenzióját én is megtapasztaltam. A tanulók szerint értelmetlen, számukra érthetetlen dolgokat kell megtanulniuk: ,Semmi értelme olyat tanitani, hogy egy-, meg kétlaki, meg a szölö bogyós gyümölcs (...) Nekik tenni kell, meg venni (...) Azt mondta az egyik nyolcadikos fiú, hogy ö ezt nem birja. Adjak neki valami munkát, aminek van értelme. De ilyeneket tanulni hülyeség. Olyan dolgot várunk el töle, ami lehetetlen. Persze hogy nem tud megfelelni." [2011, 09. 19.]

\section{A megoldás akadályai, lehetőségei (a teljesség igénye nélkül)}

Meggyőződésem, hogy a probléma megoldásának legnagyobb akadálya a véleménydiktatúra (Szontagh, 2007). Többször megtapasztaltam, amikor a nehézség felvállalása, a kiútkeresés és a segítségkérés közben falba ütköztem. Jellemző az is, hogy a probléma felvállalása után a pedagógus megkapja a „sikertelen pedagógus” vagy „alkalmatlan" címkéket.

„Ha nem tetszik valami, el lehet menni!"

„Senkit nem bilincseltek az iskola keritéséhez. Bármikor el lehet menni és más munkahelyet keresni!"

„Örülj, hogy neked még van munkád!”

„A mi iskolánkban kétféle tanár van: a vak és a látó. A vak nem bír a gyerekekkel, nem ura a helyzetnek, de nem látja. A látó, aki nem bir a gyerekekkel és nem ura a helyzetnek, és tudja." 
Ez a szemlélet, épp azokat ítéli némaságra, akik mindennapi gyakorlati tapasztalatuk révén, hozzásegíthetnének minket, hogy rálássunk a problémáinkra, s ezzel közelebb vihetnének minket a megfelelö programok, módszerek kidolgozásához. Ez a látásmód okozhatja azt is, hogy épp azok nem férnek hozzá a számukra valóban létfontosságú forrásokhoz, akiknek a legnagyobb szüksége lenne rá. Nem nélkülözhetjük a „fronton szolgálatot teljesítők” nézőpontjait, és nehézségeik megismerését. De hogy hallatni merjék hangjukat, ahhoz szükség lenne arra, hogy a rendszer értékelje azokat az önreflexióra képes intézményeket, pedagógusokat, akik szembe néznek nehézségeikkel, hibáikkal és készek a változásra.

Lényeges továbbá a tantestületek egységessége, kohéziójának erősítése, ami elengedhetetlen a problémák hatékony kezeléséhez.

„Úgy könnyebb tanitani, ha minden kollégám úgy jön be reggel, hogy tanitani fogok. Ha az egyikünk megengedi, hogy a gyerekek azt csináljanak órán, amit akarnak, vagy nem tanit, nem követel, akkor a többieknek is nehezebb dolguk van."

A szülőkkel való kapcsolattartás és együttmüködés során átláthatóbbá válik az iskola múködése a családok számára, az iskola számára pedig kirajzolódnak a szülők elvárásai, hiedelmeik és nézetrendszereik. Mindez sikeressé teheti a pedagógus-szülő együttmüködést, ami csökkentheti a fegyelmezési problémákat is. Azt a nézetet kell képviselnünk, hogy az iskola nem képes a szülők segítsége nélkül megoldani minden problémát.

„Ma kimentem az egyik diákom szüleihez. Mondtam nekik, hogy a segitségükre van szükségem. A fiúk nem hajlandó dolgozni, ö is azt hiszi, hogy én is elmegyek, és ennek az lesz a következménye, hogy majd nem kell tanulniuk. Nem akarok neki már több egyest adni, mert már így is osztályismétlő. Megkértem öket, segitsük együtt át a következö évfolyamba. Kedvesek, nyitottak voltak. (...) A fiúval a héten minden rendben volt. Tanult, nem lázongott, udvarias volt. Rá sem lehet ismerni.".

$\mathrm{Az}$ is fontos lenne, hogy ne csak egy kapcsolattartója legyen az iskolának. Azt figyeltem meg, hogy így csak a kapcsolattartót és nem az iskolát, a pedagógusokat fogadják el a diákok és a családok.

Az időhiányt, mint a szülőkkel való kapcsolattartás egyik fő akadályát, fontosnak tartom kiemelni. Megtapasztaltam, hogy gyakorta mennyire valós, a pedagógusok között sokat emlegetett probléma, ami nem feltétlenül orvosolható pusztán a nevelők szemléletváltásával. A kollégáim egy része, napi megélhetési gondjai miatt, az utolsó órája után, ha nincs szakköre, másodállásába rohan.

A fegyelmezési problémák felmerülésekor a pedagógusok az eszköztelenséget is gyakran emlegetik, de féltik állásukat, ezért csak egymás között beszélnek erről. Külső segítséget nem kérnek, mégis jellemzően a probléma felülről jövő megoldását várják. A külső szemlélőhöz azonban, csak az az üzenet jut el, hogy „kezelni tudjuk a helyzetet".

A kollégák, a szegregáció problémáinak kezelésében a kéttanáros modellt (egy tanár oktat, egy fegyelmez) tekintik hatékony megoldásnak. Igazságtalannak vélik, 
hogy az iskolára, a pedagógusra hárul, egy súlyos, komplex társadalmi problémakövetkezménye. Továbbá túlzottan hangsúlyosnak találják az adminisztrációs feladatok ellátását s ezek külső ellenőrzését, ehhez képest hangsúlytalannak nevelési feladataik ellátásának elismerését, értékelését.

Megfigyelhető a hangsúlyeltolódás az agresszió kezelésében is. A gyerekek egymás közötti agresszív magatartása, illetve annak kezelési lehetőségei nem, viszont a tárgyak rongálása (padok firkálása, ajtók rongálása) visszatérő témája a tanári értekezleteknek.

Nem felejthetjük el azonban, hogy a szemléletváltásnak, a megfelelö segítség kérésének és igénybevételének lehetősége, valamint a tárgyi és személyi feltételek javításának együttese lehetne csak képes arra, hogy a fent leírt problémákat a rendszer kezelni tudja. Hangsúlyozni kell azt is, hogy az agresszív viselkedés, az alulteljesítés, a hátrányos helyzet nem egyik napról a másikra alakult ki, így megoldásuk is csak egy hosszú folyamat eredménye lehet.

\section{Irodalom}

Aronson, E. (2001/2003): A társas lény. KJK-KERSZÖV Jogi és Üzleti Kiadó Kft, Budapest.

Csányi Vilmos (2000): Az emberi természet. Vince Kiadó, Budapest.

Katona Nóra, Szitó Imre (2005): Szerepkonfliktusok felismerése és kezelése a pedagógusszülő kapcsolatban. Mester és Tanítvány, 7. sz. 47-59. Letöltés ideje: 2012. február 20. http://www.btk.ppke.hu/uploads/files/07.pdf

Kósáné Ormai Vera (2005): Magatartási zavarok - szociális inadaptáció, In: Balogh László - Tóth László (szerk.): Fejezetek a pedagógiai pszichológia köréböl. Neumann Kht., Budapest. n.a. Letöltés ideje: 2012. február 20.

http://mek.niif.hu/04600/04669/html/ index.htm

Központi Statisztikai Hivatal Komárom-Esztergom Megyei Igazgatósága (2008): Nagyvárosok belső tagozódása. Tatabánya - KSH. Tatabánya, 62-67. Letöltés ideje: 2012. február 20. http://bit.ly/QG6kbw

Ranschburg Jenő (2008): A család anyagi helyzetének szerepe a gyermekkori magatartási zavarok kialakulásában. In: Sallai Éva - Szilvási Léna - Trencsényi László (szerk.): Módszerek a hátrányos helyzetü tanulók iskolai sikerességének segitésére, pedagógiai koncepció. Educatio Társadalmi Szolgáltató Közhasznú Társaság, Budapest, 101-118. Letöltés ideje: 2012. február 17. http://www.wekerle.gov.hu/?oldal_id=815

Szilvási Léna (szerk., 2008): Egyenlötlenségek hatása a gyerekek fejlődésére. Educatio Társadalmi Szolgáltató Közhasznú Társaság, Budapest. Letöltés ideje: 2012. február 17. http://www.wekerle.gov.hu/?oldal_id=815

Szontagh Pál (2007): Érték, rend, értékrend az iskolában. Iskolakultúra, 2. sz. 125-128. Letöltés ideje: 2012. február 20. http://epa.oszk.hu/00000/00011/00112/pdf/2007-2.pdf 